\title{
Wstęp
}

\section{My, świadkowie}

Ryszard Nycz

TEKSTY DRUGIE 2018, NR 3, S. 7-17

DOI: $10.18318 /$ td.2018.3.1

1.

We współczesnej refleksji nad świadectwem i świadkami, których status i znaczenie systematycznie rośnie, coraz bardziej potrzebne okazuje się, mam przekonanie, poszerzenie pola i zróżnicowanie badawczych perspektyw analizy. „Era świadectwa” (Felman) i „era świadka” (Wieviorka) obejmuje dziś już ponad stulecie, w którym za inicjalną falę pisarstwa testymonialnego w nowoczesnym znaczeniu przyjmuje się zapiski uczestników Wielkiej Wojny, drugą falę stanowią świadectwa Zagłady i Il wojny, a trzecią - fala relacji świadków z niekończącego się pasma ludobójczych konfliktów, katastrof, migracyjnych, uchodźczych i wygnańczych ruchów ludności, z którą od lat 70. do dziś nieprzerwanie mamy do czynienia'. Polski kontekst ma swą lokalną specyfikę (która jednak nie powinna blokować możliwości uwzględnienia tej szerszej perspektywy); świadectwa Wielkiej Wojny nie są zbyt liczne (być może trzeba by tu uwzględniać wcześniejsze relacje z doświadczeń imigracji zarobkowej), a świadectwa z doświadczeń współczesnych konfliktów, ka-

1 Zob. np. na ten temat M. Givoni Witnessing/Testimony ,"Mafte'akh" 2011 issue $2 e$.
Ryszard Nycz - prof. dr hab., kierownik Katedry Antropologii Literatury i Badań Kulturowych U], pracownik IBL PAN. Redaktor naczelny "Tekstów Drugich". Członek rzeczywisty PAN i członek korespondent PAU, KNoL PAN I KNoK PAN. Przewodniczący Komitetu Redakcyjnego serii „Nowa Humanistyka". Ostatnio opublikował: Poetyka doświadczenia.Teoria - nowoczesność literatura (2012) i Kultura jako czasownik. Sondowanie nowej humanistyki (2017). Kontakt: ryszard. nycz@uj.edu.pl 
tastrof, przemieszczeń uchodźczych zawdzięczamy przede wszystkim prozie reportażowej.

Oczywiście, kluczowa, paradygmatyczna wręcz rola świadectw Zagłady nie ulega wątpliwości w każdym z tych kontekstów, jakkolwiek poszerzenie pola uwagi skłania m.in. do szukania ogólniejszych determinant oraz charakterystyk samego zjawiska. Ważne jest, by pamiętać, że przez długi czas świadectwa te rozpatrywano przede wszystkim w dualistycznych kategoriach oprawcy i ofiary, czego konsekwencją było m.in. interpretowanie postaw i zachowań świadka w relacji do (a nierzadko i w ramach) jednej z tych skrajnie odmiennych ról. Sytuację tę zmienia, jak się uznaje, klasyczna książka Raula Hilberga z 1992 roku, która "tego trzeciego" wprowadza na scenę poznania jako istotnego uczestnika zagładowego świata i doświadczenia oraz czyni go osobnym obiektem uwagi i coraz szerzej zakrojonych interpretacji. Jak wiadomo, wydany w 2007 roku polski przekład tej książki, dokonany przez Jerzego Giebułtowskiego i zatytułowany Sprawcy, ofiary, świadkowie. Zagłada Żydów 1933-1945 proponuje dla wybranego przez autora określenia "bystander" (a nie "witness") oswojony w polszczyźnie termin "świadek", co stało się wkrótce zarzewiem trwającego do dziś sporu, w toku którego coraz powszechniejsze uznanie, jak się zdaje, zyskuje określenie „postronny” jako możliwy do przyjęcia ekwiwalent angielskiego terminu.

\section{2.}

Ze swej strony sądzę, że niezależnie od arcysłusznej potrzeby nazewniczego niuansowania postaw i zachowań ocalonych, przeżywców, gapiów, obserwatorów, postronnych, beneficjentów, ułatwiaczy..., powinny być także zachowane pozycja, rola oraz nazwa świadka, bo określają one doświadczenie nie mniej kluczowe od sprawcy i ofiary, a niezastępowalne przez tamte określenia. O tym, że to potrzebne, przekonuje mnie założycielski tekst polskiej tradycji badawczej; niewielki, lecz niezwykle ważny esej Jana Błońskiego Biedni Polacy patrzą na getto. Uważam ten tekst za fundacyjny głównie z czterech powodów. Po pierwsze, na pięć lat przed ukazaniem się książki Hilberga (był opublikowany w styczniu 1987 roku) czyni świadka odrębną kategorią badawczą. Po drugie, w roli świadków Zagłady obsadza polskie społeczeństwo jako całość, naród, jak dziś władza lubi powtarzać. Po trzecie, sytuuje owych świadków Polaków nie na zewnątrz śmiercionośnych wydarzeń, lecz w ich obrębie, jako biernych, pasywnych uczestników "granicznego" doświadczenia, które przypadło im w udziale (bo nie było przecież - w większości - rezultatem ich wyboru, intencji czy decyzji).

Argumentacja Błońskiego wskazuje tym samym na znaczące przemieszczenie statusu świadka z pozycji testis (że posłużę się klasyczną nomenklaturą przywołaną przez Agambena) - naocznego świadka, składającego relacjęz wydarzeń obok których 
(tzn. poza którymi) się znajdował - do pozycji superstes: dającego świadectwo własnemu przeżyciu i doświadczeniu (a więc pozostającemu w relacji partycypacji wobec) wydarzeń, które były jego udziałem, również tych, które wykraczały poza możliwości naocznej obserwacji, były świadczeniem niewidzialnemu i nieludzkiemu... Ta zmiana jest bardzo istotna. Mówiąc w uproszczeniu, świadek w sensie prawnym (testis) zawdzięczał swą bezstronność właśnie owej własnej bierności i pasywności, które były znamieniem zachowania neutralnego, „zewnętrznego" stanowiska obserwacyjnego. Natomiast dla świadka dającego świadectwo temu, co doświadczył (superstes) z wnętrza doświadczanego świata, żadna zewnętrzna, neutralna pozycja czy ochronna bariera nie była dostępna, a jego bierność i pasywność była, tak jak aktywność i sprawczość, właśnie formą udziału, współbycia, kontaktu, wzajemnych powiązań z ludźmi i wydarzeniami owego świata.

Dlatego zapewne, po czwarte, Błoński podejmuje wprost problem współodpowiedzialności świadka wobec wydarzeń, które stały się jego udziałem, ujmując tę relację współodpowiedzialności Polaków w kategoriach etycznych: współwiny, a nie współudziału społeczeństwa jako całości (tu w sensie: świadomego uczestnictwa, aktywnego zaangażowania „pomocników śmierci” - które to postawy dostrzegał, choć znanej dziś skali pewnie nie podejrzewał, ale wzbraniał się przed rozciąganiem ich na całe prawie dwudziestomilionowe polskie społeczeństwo czasu wojny i Zagłady). Z tego punktu widzenia nie ma istotnej różnicy między stanowiskiem Błońskiego sprzed 30 lat a dzisiejszym Grossa („nic-nie-robienie w obliczu Zagłady też jest działaniem”) czy Goldberga („nie istnieją niewinni bystanderzy”) ${ }^{2}$.

Uważam, że esej Błońskiego byłświadectwem nie tylko wielkiej odwagi cywilnej (co potwierdziła ogromna fala hejtu - nazwa wówczas nieznana, ale zjawisko jak najbardziej), lecz także przenikliwości i rozwagi. Z czego oczywiście nie wynika, że powinien być immunizowany na krytyczne odczytania, rozwinięcia, korekty czy dopowiedzenia. Ale z drugiej strony nie powinien być marginalizowany; poza wszystkim innym po 30 latach pozostajemy w dalszym ciągu w kręgu zidentyfikowanych tam problemów i dylematów, zainicjowanych rozpoznań polskiej mentalności i rozstrzygnięć etycznych, a także równie wysokiej co wówczas temperatury emocjonalnych reakcji na współcześnie podejmowane dociekania o polskich świadkach Zagłady.

2 Zob.J.T. Gross Sprawcy, ofiary i inni „,Zagłada Żydów. Studia i Materiały"2014 nr 10; R.A. Goldberg The Bystander During the Holocaust, "Utah Law Review" 2017 No. 4. Notabene ta etyczna kwalifikacja bierności jako nagannej winna być skorelowana z pragmatyczną perspektywą niedostatecznej „bierności pożądanej," którą lapidarnie ujął Laurence Weinbaum w znanym artykule w „Washington Post" (21.04.2015): „gdyby nie aktywny udział lokalnych mieszkańców, więcej Żydów przetrwałoby wojnę". 


\section{3.}

Postawa świadka, niesprowadzalna do innych postaw i zachowań, charakteryzowana była (o czym wiedzą doskonale badacze tej problematyki) przez wielu polskich pisarzy czasu Zagłady, wojny i okresu tużpowojennego; przez Nałkowską, Borowskiego, Miłosza, Różewicza (oraz wielu innych pisarzy i autorów świadectw). By unaocznić, o co mi chodzi, posłużę się parozdaniową notatką sporządzoną przez Zofię Nałkowską w jej Dziennikach pod datą 29 kwietnia 1943 roku:

Żyję obok tego, mogę żyć! Ale wreszcie jest ze mną źle, wreszcie zmieniam się w kogoś innego. Jak mogę być do tego zmuszona, żeby w tym być, żeby już tylko żyjąc - przystawać! Jest to jeszcze hańbą, nie tylko męczarnią. Jest to straszny wstyd, nie tylko współczucie. Wszelkie wysiłki, by wytrzymać, by nie dostać obłędu, by jakoś zachować siebie w tej grozie, uczuwa się jak winę. ${ }^{3}$

Sześć krótkich, eliptycznych i eufemistycznych (ze względu na obawę przed przejęciem zapisków przez niepowołane ręce) zdań to niejedyny zapis Nałkowskiej dotyczący jej reakcji na powstanie w getcie warszawskim. Ale skupia się w nich, jak sądzę, prawdziwie modelowy (jeśli nawet rzadki - traktuję go tutaj jako casus jednostkowego doświadczenia) zespół cech polskiego świadka Zagłady."Żyję obok tego..." - Nałkowska sytuuje swą pozycję wyjściowo w pozycji świadka prawnego (testis), który jest obok zdarzeń, a więc poza nimi, na quasi-bezpiecznej pozycji zewnętrznego obserwatora. Ale już sarkastyczno-ironiczne dopełnienie tego krótkiego zdania - „mogę żyć!” - czyni tę neutralność, bezstronność złudzeniem, możliwością czysto iluzoryczną. Mury getta nie chronią bowiem psychiki świadka, usytuowanego po ich drugiej stronie, przed zewem cierpień umierających za murem Żydów. Następne zdanie podważa z kolei założenie o rutynowym trwaniu dotychczasowego sposobu życia i stabilności tożsamościowej podmiotu: „Ale wreszcie jest ze mną źle, wreszcie zmieniam się w kogoś innego” - co jest przez autorkę odnotowywane z pewnym uznaniem („wreszcie”) jako właściwa (etycznie?) reakcja na traumatyczne doświadczenie.

W kogo się zmienia? Nie wiemy. Jeśli jednak wstrząs, który nastąpił, był doznaniem cierpienia, inwazyjnym wniknięciem cierpienia Żydów (jak zanotowała dzień wcześniej: „Nie mogę wytrzymać myśli, zmieniam się od nich"4) w tożsamościową osobność i autonomię podmiotu, to można uznać, że ten „ktoś inny”, to ktoś nawiedzany już odtąd przez kogoś innego i jego niewyobrażalne doświadczenie. Można by powiedzieć

3 Z. Nałkowska Dzienniki, t. 5: 1939-1944, oprac., wstęp i komentarze H. Kirchner, Czytelnik, Warszawa 1996, s. 446.

4 Tamże. 
uogólniająco, że świadek jest świadkiem wtedy, gdy świadczy; a świadczy nie w swojej przecież sprawie, a innego, i tego innego oraz jego doświadczenie czyni częścią siebie (swojej roli, zadania, tożsamości), a sprawę - własną sprawą.

Następne zdanie pozwala uczynić jaśniejszą przyjętą tu różnicę między udziałem a uczestnictwem oraz uchwycić ich pokrewieństwo, polegające na tym, że i jedno, i drugie zakłada pozostawanie wewnątrz i wystawienie na odziaływanie totalnej rzeczywistości: "Jak mogę być do tego zmuszona, żeby w tym być, żeby już tylko żyjąc - przystawać!”. Rozumiem to tak: tego, co przypada nam „w udziale” - w odróżnieniu od "uczestnictwa”, zakładającego intencjonalny wybór, świadomą decyzję, zaangażowanie - nie chcemy, ani nie wybieramy, ale musimy uznać, wziąć na swoją odpowiedzialność, bo jest częścią rzeczywistości, w której żyjemy („zmuszona, żeby w tym być' $)$ i która jest częścią nas samych: nawet zwykłe fizyczne pozostawanie przy życiu ( „już tylko żyjąc") w tych warunkach totalnego zniewolenia oznacza de facto jego legitymizowanie („przystawanie” na to, co przez Niemców dyktowane, zarządzane, bestialsko decydowane).

Ta "moja” bezwarunkowa podległość zaczyna potrącać o podłość: „Jest to jeszcze hańbą, nie tylko męczarnią". Jak rozumiem (i jak próbuję tu rekonstruować sposób myślenia i przeżywania autorki): nie tylko doznaję empatycznie "męczarni", ale także odkrywam odarcie z własnej godności, resztek czci własnej, szacunku dla siebie samej/ ego, którego poczucie jeszcze, wydaje się, zachowałam/em ("jest to hańbą"). Stąd: "Jest to straszny wstyd, nie tylko współczucie”. „Współczucie" może poprawiać nam samopoczucie jako świadectwo zdolności do współodczuwania i współrozumienia doświadczenia innego. „Wstyd” (idę tu za lekcją Eliasa) jest zaś uznaniem naszej niezdolności do sprostania wyzwaniu, zadaniu, roli, oczekiwania społecznego (czy po prostu ludzkiego). Jest lękiem przed społeczną deprecjacją i pogodzeniem się z tym werdyktem jako przyjętą przez nas wewnętrzną samooceną. Tak więc pocieszamy się myślą o naszej reaktywnej moralnej wrażliwości, zdolności do współodczuwania cudzego cierpienia, lecz to alibi nie równoważy wcale poczucia winy, rodzącego się ze świadomości naszego nie-działania, bierności, niezdolności do jakiegokolwiek aktywnego sprawstwa...

Ostatnie zdanie jedynie dopowiada tę konkluzję: „Wszelkie wysiłki, by wytrzymać, by nie dostać obłędu, by jakoś zachować siebie w tej grozie, uczuwa się jak winę". Dzieje się tak, bo nasz instynkt samozachowawczy, a może przyrodzony narcyzm, nie jest w stanie przeważyć szali etycznego zobowiązania: doświadczenie graniczne (w sensie Jaspersa) i trauma będąca konsekwencją tego doświadczenia - współbytowania w tej samej przestrzeni, poddanej tym samym prawom - czyni nas współwinnymi wydarzeń i ludzkich losów, choćbyśmy nie mieli żadnej realnej możliwości sprawczego przeciwdziałania krzywdzie, dokonującym się zdarzeniom. 
Oczywiście, należy zachować dużą ostrożność w czynieniu tego rodzaju może wyjątkowego, acz budującego etycznie świadectwa standardową czy bardziej rozpowszechnioną postawą polskich świadków Zagłady5. Niemniej jednak jest postawą faktyczną oraz wiarygodną (na ile status świadectwa pozwala to uznać), co zawdzięcza, jak sądzę, mocnej indeksalnej więzi z zaświadczaną realnością. Świadek jest świadkiem tego, co przeżył, będąc wtedy i tam, a co teraz do nas dociera w postaci językowego świadectwa, które z kolei znaczy nie tylko, a nawet nie tyle swą treściową zawartością (pojęciową reprezentacją stanu rzeczy, prawdziwością rozumianą korespondencyjnie), ile tym, co się ujawnia, co dochodzi do głosu między i poza słowami - w elipsach, rozstępach, niedopowiedzeniach, przemilczeniach, a także narastających, prawie wyłącznie afektywnych kategoriach (hańba, męczarnia, wstyd, współczucie, obłęd, wina) testymonialnego przekazu - w odczuwanych znaczeniach, doznaniach, symptomach niesionych przez ewokowaną egzystencjalną sytuację.

Językowe świadectwo nie niesie autonomicznego (pozakontekstowego, wewnątrzjęzykowego) znaczenia, jego sens szuka raczej dopiero swego wyrazu, wyłania się z sytuacyjnego osadzenia świadczącego podmiotu oraz całej „symptomatologii"(określenie Nietzschego) cielesnych zachowań i ekspresji generowanych przez bodźce dochodzące z dookolnego otoczenia, z sieci oddziaływań empirycznego środowiska, w którym się podmiot znajduje. Z czego wynika, że bez próby aktywowania cech sytuacyjnego osadzenia oraz odczytania indeksalnych znamion wpisanych w ciało świadczącego podmiotu - i "ciało" tekstu - świadectwo pojęte w tym drugim, „przeżyciowym” znaczeniu traci całą specyfikę testymonialnego przekazu ${ }^{6}$.

Tego zaś, jak ważne jest zachowanie indeksalnej relacji z zaświadczaną rzeczywistością, najlepiej dowodzi argument z falsyfikatu. W quasi-świadectwie Wiłkomirskiego (czy Demidenko, czy Defonseca, czy innych) po wykryciu „indeksalnego wiarołomstwa” ich autorów (nie byli wtedy i tam, gdzie świadczyli, że byli) nie zmienił się nawet jeden przecinek - zapis pozostał identyczny - a tekst nie został po prostu przekategoryzowany na inny gatunek dyskursywny (Veronica Tozzi sądzi co prawda, że opowieść

5 Zachęca do tego zresztą m.in. sama Nałkowska, wspominając pod datą 14 grudnia 1943 roku pomagającego w pracach gospodarskich pana Feliksa, który wówczas „pracował nad rozwalaniem gruzów" getta i „przyniósł do domu znalezione tam nożyczki i cukierniczkę, która może nawet jest srebrna, a także trochę drzewa na opał. [...] «To jest cmentarzysko» mówi jeszcze. I nie może się uspokoić" (Z. Nałkowska, Dzienniki, t. 5: 1939-1944, s. 502). Autorka rejestruje te ambiwalentne czynności (i uczucia) pana Feliksa, powstrzymując się od komentarzy, lecz sam zapis świadczy, że były to czynności (a pewnie też i uczucia) nierzadkie wówczas u warszawiaków, polskich świadków Zagłady.

6 Takjakz drugiej strony skali tę specyfikę w minimalnym stopniu zawierać może nawet bezsłowne zachowanie świadka, który - niczym stary wiarus z Warszawianki - sobą świadczy o doniosłej dla współczesnych faktyczności onegdajszego wydarzenia... 
Wiłkomirskiego można czytać jako przydatną poznawczo literacką fikcję7, czego wszakże nikt nie robi), lecz „jednomyślnym głosem” publicznej opinii został strącony z piedestału wzorcowego holokaustowego świadectwa - na którym go sytuowały wcześniej oceny najwybitniejszych ekspertów i specjalistów - i praktycznie wyeliminowany z czytelniczego obiegu, trafiając do kategorii kuriozów (w najlepszym przypadku, jeśli nie po prostu śmieci).

Z kolei zastrzec należy, że zachowanie indeksalnej wiarygodności nie chroni wcale przed błędem czy omyłkami; znak indeksalny jest, wedle Peirce'a, znakiem tylko dwuelementowym („zdegenerowanym”), zaświadcza, że coś było, że coś się wydarzyło, ale nie pozwala uchwycić sensu, dowiedzieć się, czym było to, co się wydarzyło (do tego potrzebny jest trójelementowy symbol i wpisany weń proces nieustannej interpretacji). Jak wyznała Charlotta Delbo: „dzisiaj już nie jestem pewna, czy to, co napisałam, jest prawdą, ale jestem pewna, że się wydarzyło"8. Lawrence L. Langer zwraca uwagę, że w tym zdaniu Delbo gra bliskoznacznymi określeniami: vrai - véridique - i dopowiada: "Odróżniając vrai od véridique, Delbo akcentuje różnicę między abstrakcyjnym charakterem odzyskanej prawdy a konkretem doświadczonej chwili. Ukazuje także przepaść dzielącą słowa od wydarzeń, które mają zostać słowami ożywione"9. Można zauważyć, że polska tłumaczka znalazła trafny ekwiwalent dla wyrażenia specyfiki testymonialnego doświadczenia i przekazu: kluczowej wiarygodności indeksalnej („jestem pewna, że się wydarzyło") - bo tam wtedy byłam; i wystawionej na ryzyko pomyłki czy błędu próby słownej, symbolicznej interpretacji, pojęciowego uchwycenia sensu wydarzenia („nie jestem pewna, czy to, co napisałam, jest prawdą”).

\section{4.}

Świadectwo Nałkowskiej ma cechy modelowe; nie tylko dlatego, że pozostaje wierne indeksalnie "prawdziwościowej” specyfice testymonialnej wypowiedzi, ale też z tego powodu, że jest również świadectwem drugiego stopnia - świadectwem świadczenia przez polskiego świadka Zagłady. Nałkowska nie mówi o tym, co widziała (co np. zdecydował się zrobić Jan Karski, by złożyć z tego, co widział, świadectwo) ani co się

7 Zob.V.Tozzi Przywileje świadectwa. Historia, pamięć i literatura wsporach o konstruowanie nieodległej przeszłości, przekł. E. i J.Zięba, przekł. fragmentów hiszpańskich A. Calderon Puerta, przekł. przejrzał i poprawił M. Maryl, „Teksty Drugie” $2010 \mathrm{nr} 6$.

8 Zob. Ch. Delbo Żaden z nas nie powróci, przeł. K. Malczewska-Giovanetti, Państwowe Muzeum Auschwitz-Birkenau, Oświęcim 2002, s. 105.

9 L.L. Langer Świadectwa Zagłady w rumowisku pamięci, przeł. M. Szuster, Żydowski Instytut Historyczny, Warszawa 2015, s. 58. 
wydarzyło (bo nie widziała powolnej zagłady warszawskiego getta), lecz rejestruje i próbuje nazwać własną reakcję (intelektualną, przeżyciową, etyczną, doznaniową, afektywną) na sygnały i bodźce dochodzące z tamtej strony potwornej rzeczywistości. Ale jest w tym świadectwie również coś więcej: za sprawą sposobów, w jakie rejestruje status i pozycję (poznawczą, egzystencjalną) podmiotu, jego usytuowanie wewnątrz rzeczywistości doświadczanej oraz cechy samego doświadczenia (poznawcze, afektywne, doznaniowe), które prowadzą do podmiotowej, tożsamościowej przemiany Nałkowska prowadzi nas do przypuszczenia, że bycie świadkiem owego granicznego doświadczenia nie stanowi roli, jednej z wielu, którą można porzucić i zastąpić innymi wyborami, lecz staje się trwałym składnikiem własnego doświadczenia, konstytuującym jednostkową podmiotowość i tożsamość. Jej jądrem jest wychylenie ku innemu, uczynienie doświadczenia innego komponentem własnego tożsamościowego wyposażenia, traumą wpisaną w kondycję (świadczącego) podmiotu.

Ten ostatni trop - świadka jako figury podmiotu - zachęca do próby zbadania odwrotnej relacji i do poszerzenia perspektywy refleksji nad świadkiem także w inną stronę: nowoczesnych i współczesnych koncepcji podmiotu jako świadka. Jest to ogromny problemowo obszar zjawisk, który tu mogę tylko zasygnalizować. Jedną, odrębną tradycję tworzy anglosaska epistemologia świadectwa (rozpatrywana na ogół jako część epistemologii przekonań), gdzie kwestią kluczową i kryterialną jest językowy, dyskursywny charakter samego świadectwa (kto nie składa językowego świadectwa, nie jest świadkiem). Z polskich filozofów zbliżała się do tej orientacji koncepcja Barbary Skargi, zdaniem której, „by dać świadectwo, trzeba je wypowiedzieć, a więc ująć w słowa. Póki nie powiem, że tak a nie inaczej jest lub było, świadectwa nie ma. [...] Świadcząc tylko interpretujemy"10. Inną, zupełnie osobną orientację tworzą antropologiczno-etnologiczne koncepcje poznania partycypacyjnego, w których badacz sytuowany jest w pozycji świadka, od wewnątrz poznającego świat badany - wiedza o tym świecie niejako „zapisuje się"w jego cielesnym, zmysłowym, afektywnym doświadczeniu (najciekawiej piszą o tym, moim zdaniem, Tim Ingold i Kirsten Hastrup).

Jeszcze inną konstelację współtworzą osobne wybitne indywidualności filozofii kontynentalnej, m.in.: Emmanuela Levinasa teoria „innego w tym samym”, fundująca podmiotowość na etyczno-afektywnym pobudzeniu przez innego, Paula Ricoeura figura podmiotu jako świadka (wyłożona najpełniej w O sobie samym jako innym), Michaiła Bachtina „egzotopiczna" koncepcja podmiotu, w akcie samowiedzy rozpoznającego

10 B. Skarga Kwintet metafizyczny, Universitas, Kraków 2005, s. 121-122. O anglosaskich badaniach z zakresu epistemologii świadectwa dają wyobrażenie m.in.: . Lackey Learning from Words. Testimony as a Source of Knowledge, Oxford University Press, Oxford - New York 2008; A. Gelfert A Critical Introduction to Testimony, Bloomsbury Academic, London - New York 2014; J. Shieber Testimony. A. Philosophical Introduction, Routledge, Taylor \& Francis Group, New York 2015. 
u swych podstaw obecność, spojrzenie i głos innego, Jeana-François Lyotarda dociekania o świadku i świadczeniu w Poróżnieniu, Jeana-Luca Nancy'ego koncepcja współjednostkowej jednostki, Giorgia Agambena ujęcie podmiotowości świadka i świadczącego podmiotu w sposób, który przekonuje, że „bycie podmiotem i dawanie świadectwa okazują się w ostatecznym rozrachunku tym samym"111, Jacques'a Derridy Poetyka i polityka świadczenia i wreszcie koncepcja Petera Sloterdijka, który swój esej o dziejach, wzlocie i upadku nowoczesnego podmiotu poznającego ujął właśnie w kategoriach przemian figury świadka.

Sloterdijk analizuje najpierw różne wcielenia „mitu świadka” w historii filozofii (sytuowane, mówiąc w wielkim uproszczeniu, w pozycji testis): od platońskiego kontemplującego esencje podmiotu, przez czystego, zewnętrznego, transcendentalnego obserwatora i różne "wyniosłe fikcje bezinteresownego rozumu”, w tym wewnętrznego świadka - „który w procesie życiowym jest tylko obecny, jakby we własnej duszy otworzono ekscentryczny punkt obserwacyjny" - po praktyki „ćwiczącego się w niezaangażowaniu" Husserlowskiego podmiotu zdolnego do epoche i Luhmannowskiego obserwatora drugiego stopnia. W zakończeniu zaś pokazuje jego przemianę w świadczący podmiot, zanurzony w egzystencjalnym doświadczeniu (a więc, upraszczając, jako superstes). Jego zapowiedzi znajduje u Nietzschego, a różnorodne wcielenia w głównym nurcie współczesnej filozofii:

W swych przyczynkach do krytyki rozumu Nietzsche pokazał przynajmniej to, że wszelkie poznanie ma charakter lokalny, i że żaden ludzki obserwator nie może posunąć się tak daleko w naśladownictwie boskiego oka, by transcendować swe własne stanowisko. Rada nowej krytyki poznania brzmi zatem, by zaprzestać usiłowań wyjścia z własnej skóry na rzecz chimery ponadosobistej mądrości, lecz całkowicie we własną skórę wejść, by aż po najdalsze granice wykorzystać szansę poznawczą daną w niezastępowalnej perspektywie jednostkowej egzystencji. Nie trzeba wyjaśniać, jak przez to nauka zbliża się do literatury pięknej, a teoria zmienia się w wyznanie - bez konieczności przesądzania o pierwszeństwie jednego czy drugiego. ${ }^{\mathbf{2}}$

Przywołałem na koniec tę syntetyczną obserwację Sloterdijka, choć listę filozofów profilujących w ten sposób swe koncepcje podmiotowości można z pewnością znacznie przedłużać, bo uzmysławia lapidarnie kierunek i powody przemian filozoficznych

G. Agamben Co zostaje z Auschwitz. Archiwum i świadek (Homo sacer III), przeł. S. Królak, Wydawnictwo Sic!, Warszawa 2008, s. 159.

12 P. Sloterdijk Letarg myślenia. Filozofia i nauka jako ćwiczenie, przeł. T. Słowiński, Wydawnictwo Toporzeł, Wrocław 2015, s. 125-126; wcześniejsze cytacje kolejno ze stron: 116, 122, 31. 
dociekań o podmiotowości. Prowadzą one od bezświatowego i odcieleśnionego, samoustanawiającego się i autonomicznego podmiotu racjonalnego - do ucieleśnionego, zależnego od relacji ze światem i zawisłego od innego, podmiotu doświadczenia, którego niechciany, przygodny, kontyngentny, cielesny i psychiczny udział w tej rzeczywistości stanowi rękojmię poznania jej natury.

\section{5.}

Ta ryzykowna próba zgrupowania pod parasolem figury świadka tak osobliwie różnorodnej konstelacji stanowisk i tematów służyć miała uzmysłowieniu trzech hipotez czy może tylko obserwacji. Pierwsza z nich dotyczy powinowactwa czy korelacji w statusie świadka i świadczenia, po pierwsze, na poziomie jednostkowego egzystencjalnego doświadczenia, po drugie - na poziomie konkretnej lokalnej wspólnoty pojętej jako zbiorowy świadek oraz po trzecie - na poziomie uniwersalnego modelu podmiotowości. Jak zauważa Michal Givoni, jest to dziś status przede wszystkim polityczny. Nasze czasy bowiem to nie tyle era świadka czy era świadectwa, co raczej

era stawania się świadkiem, czas, w którym jednostki są wzywane w coraz większej liczbie, nasileniu i na większą skalę do modelowania siebie jako świadków, choć ich pozycja jako świadków nie jest zagwarantowana, a sposób świadczenia jest podważany. Polityczne świadectwo, jeśli już trzeba je określić, jest sposobem mówienia "my" bez rozpuszczenia "ja" oraz bez wykluczania innego. ${ }^{13}$

Druga obserwacja to warta uwagi strukturalna zbieżność cech podmiotowego świadczenia i świadectwa. Jeśli bycie podmiotem-świadkiem, w sensie otwarcia na innego, zdolności do odnoszenia się do innego oraz odpowiadania na wezwanie innego, dowodzi, że inny jest w nas, bo stanowi nieusuwalną, konstytutywną część naszego doświadczenia i tożsamości, która jednocześnie pozostanie nieprzyswojona, boleśnie, traumatycznie obca, bo nigdy nie zdołamy jej zasymilować ostatecznie, to bycie świadectwem zawiera podobne wewnętrzne poróżnienie czy zróżnicowanie - to, co powiedziane, jest niepewnym nosicielem innego, indeksalnego przekazu, który nigdy całkowicie nie wysłowi się w klarownych pojęciach, wystawiony na szansę czy skazany na ryzyko aktywowania go w hipotetycznym doświadczeniu lektury.

13 M. Givoni Witnessing/Testimony, s. 165. Por. także inną koncepcję podmiotowości, również modelowaną na figurze świadka czy raczej podwójnej strukturze świadczenia: jako naocznego świadectwa oraz dawania świadectwa temu, co nie może być widziane - K. Olivier Witnessing and Testimony, „Parallax" 2004 Vol. 10 No. 1. 
I trzecia obserwacja: o podmiocie-świadku Zagłady. Casus świadectwa Nałkowskiej pokazywał transformację tradycyjnego podmiotu (dość narcystycznego, jak wiemy z wcześniejszych zapisów w Dziennikach) w świadka Zagłady, który to otwarcie na innego, na cierpienie i śmierć Żydów czyni składnikiem własnej tożsamości, prymarnego "my", z którego wyłania się relacyjna i zależna podmiotowość-ze-względu-na-innego. Błońskiego obsadzenie Polaków w roli świadków Zagłady zakłada, czy życzeniowo projektuje, podobną przemianę w charakterze podmiotu zbiorowego (duszy czy mentalności) - powiedzmy, przerysowując: od anima naturaliter endeciana do Polaków świadków Zagłady, którzy to „kłopotliwe dziedzictwo", jak eufemistycznie określają to heritologowie, jakie przypadło im w udziale, biorą na swoją odpowiedzialność, czynią częścią swej pamięci i przeszłości, własnej narodowej tożsamości (tego „my”, które nie wyklucza ani „ja”, ani „innego" czy „obcego"). A czy nie można powiedzieć, że Zagłada jako kluczowe wydarzenie w dziejach nowoczesności określa depozyt pamięci i aktualne dziedzictwo dla teraźniejszości, wyznacza próg, od którego biorą swój początek, nabierają ciężaru filozoficznej doniosłości oraz wagi społecznego, politycznego wyzwania dla współczesności „testymonialne" koncepcje podmiotowości?

My, świadkowie...

\section{Abstract}

\section{Ryszard Nycz}

JAGIELLONIAN UNIVERSITY (CRACOW)

THE INSTITUTE OF LITERARY RESEARCH OF THE POLISH ACADEMY OF SCIENCES (WARSAW) We, the Witnesses

Nycz presents the perspective offered by studies on witnesses and testimonies in relation to a particular model of subjectivity - a model that assumes a basic "sociality" as well as a primitive "us" that gives rise to a relational and dependent subjectivity-on-account-of-another. This model of a witness-subject or subject-witness functions on several levels: individual identity, the collective subject and the philosophical concept of universal subjectivity. Initiated by witnesses of the Holocaust, this model of subjectivity is becoming more and more important in contemporary culture.

\section{Keywords}

witness, testimony, Holocaust, subject 